\title{
Scholars and Literati at the Imperial College of Madrid (1560-1767)
}

\author{
David de la Croix Soraya Karioun \\ IRES/LIDAM, UCLouvain
}

This note is a summary description of the set of scholars and literati who taught at the Jesuit Imperial College in Madrid from its inception in 1560 to the suppression of the Society of Jesus in 1767.

\section{The UnIVERSity}

Formerly known as Casa y Colegio de la Compania de Jesus, this important Spanish institution was founded in 1560. It became imperial in 1603 thanks to the legacy of the Empress Mary of Austria, daughter of Charles V. In 1625, King Philip IV of Spain dreamed of a higher institution that would provide all the general courses of university education. He set up a large-scale project, Los Reales Estudios. This development was hindered by legal proceedings initiated by the Universities of Salamanca and Alcalá de Henares, claiming unreasonable competition and the fact that a university should not be entrusted to a single religious order. Finally, the Imperial College lost the battle and was not allowed to teach logic or award academic titles (Grendler 2019). As a consequence, Madrid had no university prior to 1836 . Still, in 1725 , a new establishment providing pre-university courses for children from the bourgeoisie opened its doors, the Real Seminario de Nobles. In 1767, the Jesuits were expelled from Spain and the Imperial College of Madrid therefore closed its doors (Simón Díaz 1952).

\section{SOURCES}

The main source used for this research is the two-volume work Historia del Colegio Imperial de Madrid (1952), published by José Simon Diaz, a Spanish professor, historian, and bibliographer. In addition to the history of the various establishments of the Imperial College, a list of the Jesuits who taught or resided at the Imperial College, as well as a valuable biographical notice, is included in the Appendix. To complete our research, we have relied on an encyclopaedia of Jesuit biographies, Bibliothèque de la Compagnie de fésus, written by Carlos Sommervogel (1890).

\section{SOME STATISTICS}

Table 1 shows some descriptive statistics. There are 386 scholars and literati. A large majority worked during the first two periods. Afterwards, the college seems to have shrunk. The year of birth is known for $53.6 \%$ of them, which is a relatively high percentage (compared with the $26.1 \%$ known at another Jesuit university, Pont-à-Mousson, see De la Croix and Karioun (2021), and the $53.6 \%$ known at the Gregorian University, the mother ship of the Jesuit education system, see de la Croix and Karioun (2021)). The mean age at appointment is 40 years old. Expected age at death when 30 is 66.6 years. The few Jesuits of the last period seem to have enjoyed greater longevity, but the sample size is very small.

The birth place is known for $92.5 \%$ of the individuals, which again is a high percentage. The median distance between place of birth and Madrid is $137 \mathrm{~km}$. Finally, $10.4 \%$, of the scholars have 
a Wikipedia page (in some language), while $22.5 \%$ of them have left a footprint in the catalogues of the libraries of the world, Worldcat, either by having published some work, or by having been the subject of published books and articles. The last number is quite low for a Jesuit university, as for Jesuits it was important to write and publish books. Perhaps here, being far away from the borderline with Protestantism, there was little incentive to publish. This is a hypothesis we would like to explore in further research.

\begin{tabular}{|c|c|c|c|c|c|c|}
\hline \multicolumn{2}{|c|}{ Period } & \multirow{2}{*}{$\begin{array}{l}\text { nb. } \\
\text { obs }\end{array}$} & \multirow{2}{*}{$\begin{array}{l}\% \text { birth year } \\
\text { known }\end{array}$} & \multirow{2}{*}{$\begin{array}{l}\text { mean age } \\
\text { at appoint. }\end{array}$} & \multirow{2}{*}{$\begin{array}{l}\text { mean age } \\
\text { at death }\end{array}$} & \multirow{2}{*}{$\begin{array}{l}\text { exp. age } \\
\text { at death }\end{array}$} \\
\hline Start & End & & & & & \\
\hline 1527 & 1617 & 118 & 87.3 & 38.1 & 69.5 & 71.8 \\
\hline 1618 & 1685 & 220 & 94.1 & 39.8 & 66.3 & 63.6 \\
\hline 1686 & 1733 & 29 & 82.8 & 47.1 & 71.2 & 70.7 \\
\hline 1734 & 1800 & 19 & 68.4 & 42.6 & 75.2 & 76.4 \\
\hline \multirow[t]{2}{*}{1000} & 1800 & 386 & 89.9 & 40 & $6 \overline{8} . \overline{4}$ & 66.6 \\
\hline & & & $\begin{array}{c}\% \text { birth place } \\
\text { known }\end{array}$ & $\begin{array}{l}\text { median distance } \\
\text { birth-institution }\end{array}$ & $\begin{array}{c}\% \text { with } \\
\text { Wikipedia }\end{array}$ & $\begin{array}{c}\% \text { with } \\
\text { Worldcat }\end{array}$ \\
\hline 1527 & 1617 & & 91.5 & 138 & 9.3 & 19.5 \\
\hline 1618 & 1685 & & 96.8 & 137 & 9.1 & 20.9 \\
\hline 1686 & 1733 & & 82.8 & 42 & 10.3 & 24.1 \\
\hline 1734 & 1800 & & 63.2 & 373 & 31.6 & 57.9 \\
\hline 1000 & 1800 & & $\overline{9} 2 . \overline{5}$ & $13 \overline{7}$ & $10 . \overline{4}$ & 22.5 \\
\hline
\end{tabular}

Table 1: Summary statistics by period

\section{FIELDS}

Figure 1 shows the relative importance of fields, broadly defined. Most of the courses given at the Imperial College of Madrid were in the humanities, such as grammar, rhetoric, arts, Latin, and philosophy. There were also several courses in theology, such as Holy Scripture or moral theology. In the field of sciences, the source reports exclusively mathematics courses. A smaller category includes some courses that were given on an exceptional basis, such as those on re militari and politics. The source does not always mention the courses given by professors: they are in the unknown category, which also includes the rectors and prefects (Simon Diaz, 1952).

\section{Place of BIRTh}

Figure 2 is a plot of the places of birth of all the scholars of the Imperial College. The faculty was quite international, with people coming from Ireland, England, France, the Holy Roman Empire, Southern Italy (with was under the same rule as Spain), and Eastern Europe.

\section{HUMAN CAPITAL OF SCHOLARS AND LITERATI}

For each person in the database, we compute a heuristic human capital index, identified by combining information from Worldcat and Wikipedia using principal component analysis. We also compute the notability of the university at each date by averaging the human capital of the scholars active at the Imperial College 25 years before that date. The details are given in the Appendix. Figure 3 shows the names of all the scholars with a positive human capital index. The orange line plots the notability of the university. The vertical green lines (rug plot) show the distribution of all scholars, including the obscure ones, over time. 


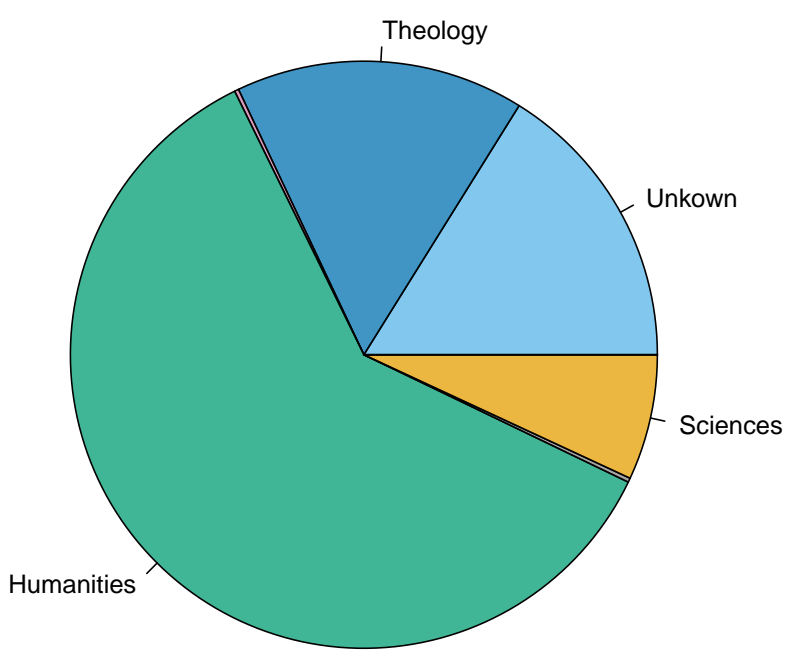

Figure 1: Broad fields at the Imperial College

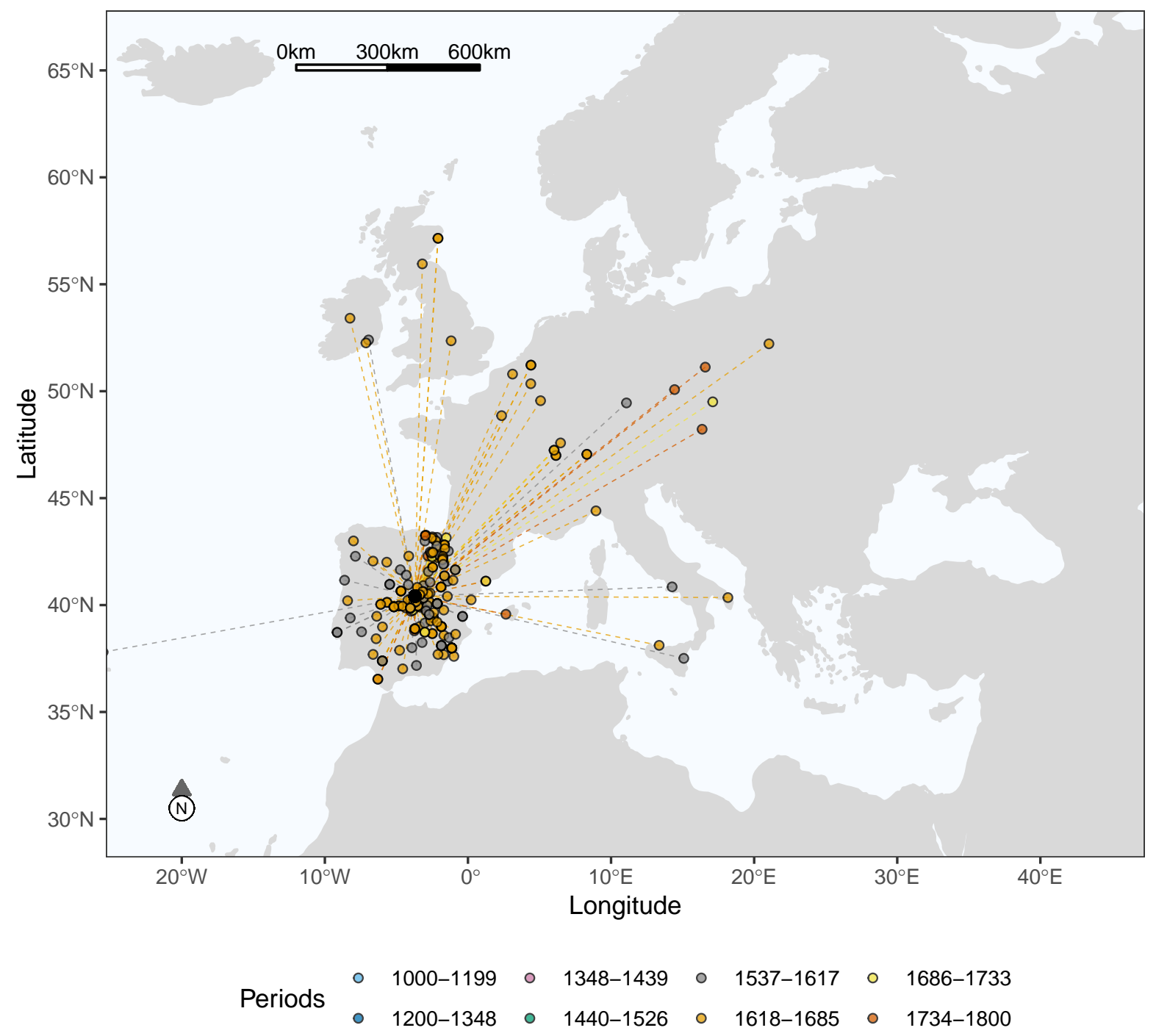

Figure 2: Place of birth of the scholars and literati at the Imperial College 


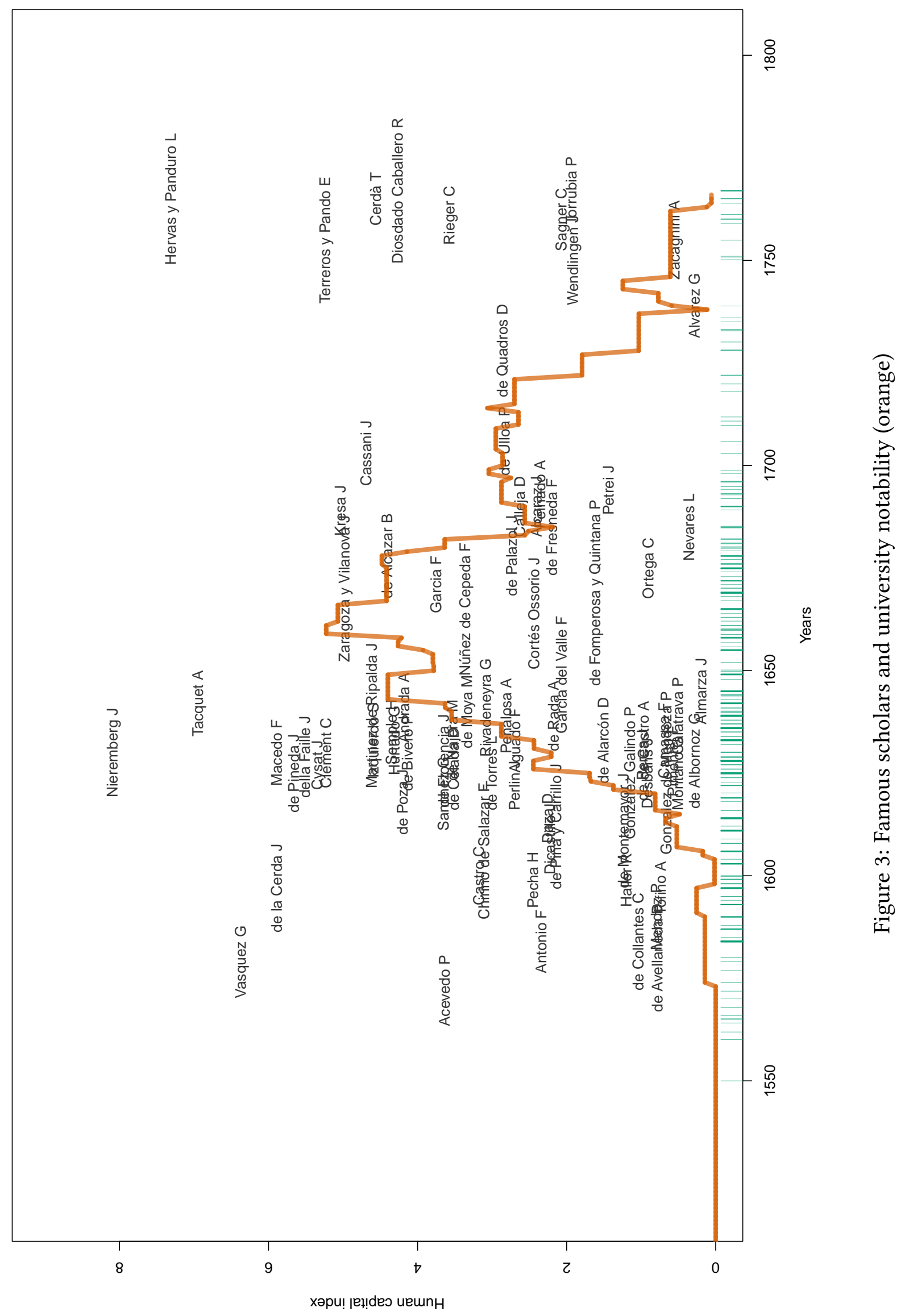


The pattern indicates that the notability of the Imperial College rose fast after its foundation and peaked in 1650. Then, the college did not escape the general decline observed in Spain after that date.

\section{TOP 6 PROFESSORS}

We provide a brief overview of the six professors with the highest human capital index.

Juan Eusebio Nieremberg (1595 Madrid - 1658 Madrid) was a theologian and philosopher of German origin. His parents were servants of Mary of Austria for years. He studied humanities and Latin at the Imperial College of Madrid and continued his education by studying law at the University of Salamanca. His numerous publications reflect an eclectic thought, oriented towards Neoplatonism. He taught natural history at the Imperial College of Madrid for over fifteen years, a chair to which he added that of Holy Scripture. He led an ascetic and sedentary life, always immersed in his research. His health was fragile, and he was paralyzed at the end of his life.

Lorenzo Hervas y Panduro (1735 Horcajo de Santiago - 1809 Rome), who came from a modest farming family, joined the Society of Jesus at the age of fourteen. He studied art, theology, and law at Alcalá de Henares and, astronomy and mathematics at the Imperial College of Madrid. He taught philosophy at several Jesuit colleges, including metaphysics at the Seminary of the Nobles. When the Jesuits were expelled, he went to Italy where he wrote his main work, a sort of encyclopaedia of studies on various subjects such as anthropology, cosmography, astronomy, and linguistics.

André Tacquet (1612 Antwerp - 1660 Antwerp) was a brilliant mathematician in Euclidian geometry who taught at the University of Louvain and at the Imperial College, at least according to Simón Díaz (1952) (but not confirmed in other sources). His presence in Madrid is however not dated. There is a controversy about whether he was a pioneer in infinitesimal calculus, as is argued for example on his Wikipedia page in French, or if instead, he led the fight against infinitesimal calculus, as Alexander (2014) argues in his recent book.

Gabriel Vasquez (1549 Belmonte - 1604 Alcalá de Henares) was one of the best-known theologians and exegetists of his time. He taught theology for many years in several Spanish cities, including Alcalá de Henares and Madrid, and in Italy, at the prestigious Roman College. A professor who enjoyed an excellent reputation for his eloquence, meticulous knowledge in various fields, and rigorous methodology, he earned the nickname of Augustinian of Spain or the Light of Theology. He is the author of numerous theological treatises, many of which were in response to the Jesuit philosopher and theologian Francisco Suarez, as they both held antagonistic positions.

Juan Luis de la Cerda (1558 Toledo - 1643 Madrid) studied theology and philosophy, and later taught grammar, rhetoric, and Greek at several Spanish Jesuit colleges. His most important position was in Murcia, where he taught poetry and eloquence for fifty years. With an outstanding erudition in poetry, he is mainly known for his commentaries on the work of Virgil.

Macedo Francisco (1594 Coimbra - 1682 Padua) entered the novitiate in 1610. A few years later, he taught humanities at several Jesuit colleges, including the Imperial College of Madrid in 1630. In 1638, he left the Society of Jesus and entered the Cordeliers, taking the name Francis of St. Augustine. From this period, he became a prolific writer, with numerous publications in various fields such as theology and philosophy. Later, he joined the Franciscan order and continued to teach throughout his life at several Italian institutions. 


\section{RELATED SCHOLARS}

Beyond those who can clearly be assigned as professors at the College, several important individuals are related to it. Here, we show two of them, who were appointed to the College but died before reaching it. Those scholars are counted to establish all figures but Figure 3.

Luis de Molina (1535 Cuenca - 1600 Madrid) was one of the most famous theologians of his time, a member of the prestigious School of Salamanca. He gave his name to his controversial doctrine, Molinism, which advocated freedom over necessity. A fervent defender of free will in divine salvation, he built a bridge between the Augustinian tradition of predestination and the ideals of the Renaissance. He taught theology and philosophy at Coimbra and Evora, before being appointed to teach moral theology at the Imperial College of Madrid. Unfortunately, in a fragile state of health, he died before he could take up his position.

Charles Malapert (1580 Mons - 1630 Vitoria) entered the noviciate in 1600. As an itinerant professor, he taught mathematics and philosophy in Lorraine, Douai, and Poland. His scientific contribution, mainly in mathematics and astronomy, was considerable, despite his modest reputation. Other contributions of Charles Malapert include poetry and dramaturgy. In poor health, he died on his way to Madrid, where he was appointed as a professor of mathematics at the Imperial College, which was fast expanding at the time.

\section{UNIVERSITY NETWORK}

Here, we assume that when a professor occupied a position at more than one university over his/her life, this established a link between those universities. The universities with which the Imperial College is linked are displayed in Figure 4. Many links can be observed in all periods, as the Jesuits often reallocated their scholars among the numerous universities that they created in Europe.

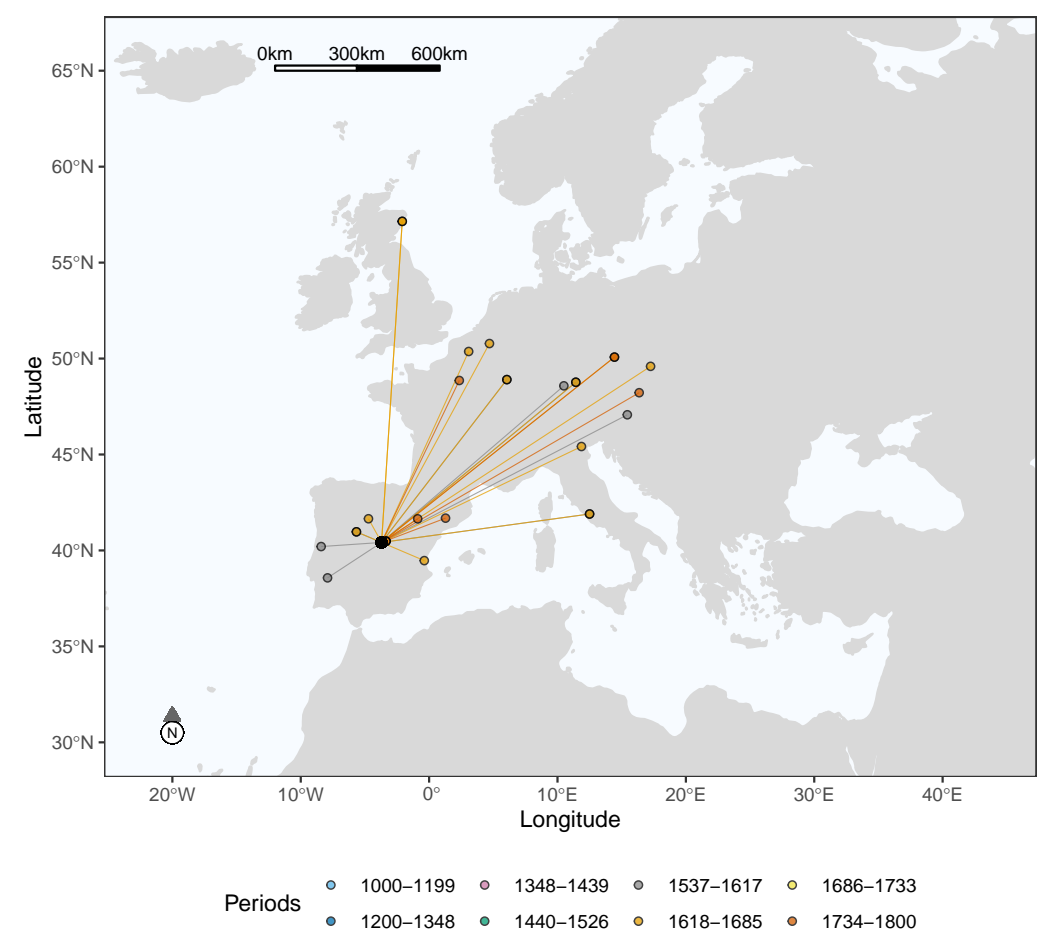

Figure 4: Links between the Imperial College and other universities through scholars' mobility, by period 


\section{APPENDIX}

The individual human capital index $q_{i}$ of an individual $i$ is given by:

$$
\begin{aligned}
q_{i}= & -1.76+0.43 \ln (\mathrm{nb} . \text { characters of the longest Wikipedia page }) \\
& +0.40 \ln (\mathrm{nb} . \text { Wikipedia pages in different languages })+0.47 \ln (\text { nb. works in Worldcat }) \\
& +0.46 \ln (\mathrm{nb} . \text { publication languages in Worldcat })+0.47 \ln (\mathrm{nb} \text {. library holdings in Worldcat })
\end{aligned}
$$

We assume that having no Wikipedia page is similar to having one page with a length of 60 characters and that having no Worldcat page is similar to having a page with one work in one language held by one library. The constant -1.76 normalizes $q_{i}$ at 0 when there is neither a Wikipedia page, nor a Worldcat page. The weights $(0.43,0.40$, etc) are obtained from the first principal component of the five indicators (De la Croix et al. 2020).

The notability $Q$ of a university aggregates the $q$ of the top 5 persons who were active in the preceding 25 years using the following formula:

$$
Q=\sqrt{\sum_{i=1}^{5} \frac{1}{5}\left(\frac{q_{i}}{s_{i}}\right)^{2}}
$$

where $s_{i}$ is the number of universities at which $i$ had an appointment.

\section{ACKNOWLEDGMENTS}

This project has received funding from the European Research Council (ERC) under the European Union's Horizon 2020 research and innovation programme, under grant agreement No 883033 "Did elite human capital trigger the rise of the West? Insights from a new database of European scholars."

First version May 17, 2021. Updated, November 25, 2021.

\section{REFERENCES}

Alexander, Amir. 2014. Infinitesimal: How a dangerous mathematical theory shaped the modern world. Macmillan.

De la Croix, David, Frédéric Docquier, Alice Fabre, and Robert Stelter. 2020. "The Academic Market and the Rise of Universities in Medieval and Early Modern Europe (1000-1800).” CEPR Discussion Paper 14509.

De la Croix, David, and Soraya Karioun. 2021. "Scholars and Literati at the University of Pont-àMousson (1572-1768)." Repertorium eruditorum totius Europae 2:1-6.

de la Croix, David, and Soraya Karioun. 2021. "Scholars and Literati at the Gregorian University in Rome (1551-1773).” Repertorium eruditorum totius Europae 3:19-26.

Grendler, Paul F. 2019. Jesuit Schools and Universities in Europe 1548-1773. Brill Research Perspectives in Jesuit Studies. Brill.

Simón Díaz, José. 1952. Historia del Colegio Imperial de Madrid. Madrid: Consejo Superior de Investigaciones Científicas.

Sommervogel, Carlos. 1890. Bibliothèque de la Compagnie de Jésus. Brussels: Oscar Schepens. 